\title{
Small-scale area effect on species richness and nesting occupancy of cavity-nesting bees and wasps
}

\author{
Rafael D. Loyola ${ }^{1} \&$ Rogério P. Martins ${ }^{2}$
}

\begin{abstract}
'Departamento de Ecologia, Universidade Federal de Goiás. Caixa Postal 131, 74001-970 Goiânia-GO, Brazil. avispa@gmail.com
${ }^{2}$ Laboratório de Ecologia e Comportamento de Insetos, Departamento de Biologia Geral, Universidade Federal de Minas Gerais. Avenida Antônio Carlos 6627. Caixa Postal 486, 30161-970 Belo Horizonte-MG, Brazil. wasp@icb.ufmg.br
\end{abstract}

\begin{abstract}
Small-scale area effect on species richness and nesting occupancy of cavity-nesting bees and wasps. The research was conducted in an urban forest remnant in southeast Brazil. We tested the predictions of the following hypotheses: (1) larger areas present higher species richness of bees and wasps, (2) solitary bees and wasps occupy more nests in larger areas, (3) rare species occupy more nests in smaller areas. We sampled Aculeate bees and wasps using trap nests from February to November 2004. We placed trap nests in sampling units (SU) with different size $\left(25,100\right.$ and $\left.400 \mathrm{~m}^{2}\right)$ located in 6 ha of secondary mesophytic forest. One hundred and thirty-seven trap nests were occupied by seven species of bees and four species of wasps. We found an increase in wasp, but not bee species richness following increase in SU size. Hymenoptera richness (i.e. bees plus wasps) was also greater in larger SU. Both the number and density of occupied nests increased with SU size. The wasp Trypoxylon lactitarse responded significantly to area size, larger SU having more occupied nests. The same pattern was exhibited by the wasp Auplopus militaris, the Megachile bee species, and the bee Anthodioctes megachiloides. Only Trypoxylon sp. was not affected by SU size. Our results show that cavity-nesting bee and wasps respond differently to the area effects. Such findings must be complemented by information on the frequency and dynamics of area colonization and nest occupancy by species of solitary Hymenoptera.
\end{abstract}

KEYWORDS. Aculeata; Brazil; forest remnant; solitary bee and wasps; trap-nests.

RESUMO. Efeito de área em pequena escala sobre a riqueza e comportamento de nidificação de abelhas e vespas solitárias. Este trabalho foi realizado em fragmento florestal urbano localizado na região sudeste do Brasil. Foram testadas as predições das seguintes hipóteses: (1) áreas maiores apresentam maior riqueza de espécies de abelhas e vespas que nidificam em cavidades pré-existentes, (2) espécies de abelhas e vespas que nidificam em cavidades pré-existentes ocupam mais ninhos em áreas maiores, (3) espécies raras ocupam mais ninhos em áreas menores. Estes insetos foram amostrados por meio de ninhos-armadilha de fevereiro a novembro de 2004. As armadilhas foram dispostas em unidades amostrais com diferentes tamanhos $\left(25,100 \mathrm{e} 400 \mathrm{~m}^{2}\right)$, alocadas em um fragmento de floresta mesofítica de 6 ha. Cento e trinta e sete armadilhas foram ocupadas por sete espécies de abelhas e quatro espécies de vespa. Observamos um aumento na riqueza de vespas associado a uma maior área amostral; não observamos o mesmo para abelhas. A riqueza de espécies de Hymenoptera (abelhas e vespas, em conjunto) foi maior em áreas maiores. Tanto a abundância quanto a densidade de ninhos ocupados por abelhas e vespas aumentou com o aumento da unidade amostral. Trypoxylon lactitarse ocorreu mais frequentemente em áreas maiores. O mesmo padrão foi observado para Auplopus militaris, espécies do gênero Megachile e Anthodioctes megachiloides. Apenas Trypoxylon sp. não foi afetada pelo tamanho da unidade amostral. Os resultados do estudo mostram que abelhas e vespas solitárias respondem de maneira diferente ao tamanho de área. O entendimento dessas relações deve ser complementado por informações sobre a frequência e dinâmica de ocupação de ninhos e colonização de áreas por abelhas e vespas solitárias.

PALAVRAS-CHAVE. Abelhas e vespas solitárias; Aculeata; Brasil; fragmento florestal; ninho-armadilha.

Increasing species richness with increasing area of investigation is one of the most confirmed generalizations in Ecology (Schoener 1976; Lawton 1999; Lomolino 2000). Numerous studies describe and interpret the underlying mechanisms of species-area relationships for different taxa, and for scales ranging from local forest remnants to the entire Globe (Connor \& McCoy 1979; Williamson 1988; Rosenzweig 1995; Drakare et al. 2006).

Positive species-area relationships are commonly observed in the field. Two explanations for such positive response include the habitat diversity hypothesis (Rosenzweig 1995) and the hypothesis of demographic colonization-extinction dynamics (MacArthur \& Wilson 1967). Species-area relationships have been used to compare species-richness values of different areas and extrapolating species richness (e.g. Colwell \& Coddington 1994), and for producing biodiversity maps (e.g. Kier et al. 2005). They have also been applied in the context of conservation biogeography for identifying hotspots for species richness (e.g. Fattorini 2007), for systematic conservation planning (e.g. Desmet \& Cowling 2004), for predicting species loss after habitat destruction (e.g. Ulrich 2005) and for evaluating human impacts on biodiversity (e.g. Tittensor et al. 2007).

As the number of species, the population density of animals can also increase with the size of a particular area. However, there are few studies on this aspect of insect population (Connor et al. 2000; Julião et al. 2004). Few authors examined simultaneously the area and habitat fragmentation 
effects on different taxonomic groups (Robinson et al. 1992). Others focused on vertebrates such as large mammals (Peacock \& Smith 1997) and birds (Schmiegelow et al. 1997), and only few were targeted at invertebrates, in particular to butterflies (Cappuccino \& Martin 1997; Sutcliffe et al. 1997). Small-scale experimental studies on the area effect on less conspicuous animals are still more scarce (but see Zschokke et al. 2000; Gonzalez \& Chaneton 2002; Braschler et al. 2003).

Given that habitat fragmentation does not affect every species on a similar way (Davies et al. 2000; Becker et al. 2010), it can alter community structure and important ecological processes, such as predation and pollination, which can suffer considerable disturbances. Further, it is known that species at high trophic levels, mutualists, habitat specialists and host plants are likely to go extinct first from the diminishing size of the habitat (Holt et al. 1999; Rathcke \& Jules 1993; Steffan-Dewenter \& Tscharntke 2002). This assumes particular importance for cavity-nesting bees and wasps given that how pollinators, predators and parasitoids (the major functional groups these insects fit in) respond to area size is still obscure (Didham et al. 1996; Harrison \& Bruna 1999; Debinski \& Holt 2000) as well as our knowledge on how this component of insect diversity respond to such habitat alterations (but see Morato \& Campos 2000; Steffan-Dewenter 2002; Loyola \& Martins 2006, 2008, 2009).

Here we investigate the effects of area size, at a local scale, on the species richness, as well as in the number and density of occupied nests in a mosaic area composed by Atlantic Forest remnants surrounded by a matrix of cerrado vegetation. In particular, we tested the predictions of the following hypotheses, related to area effects and passive sampling: (1) larger areas present higher species richness of solitary bees and wasps, (2) larger areas present a higher number of nests occupied by these species, and (3) rare species occupy a higher number of nests in smaller areas.

\section{MATERIAL AND METHODS}

Study Area. We conducted the study in a protected area at the Federal University of Minas Gerais, Belo Horizonte,

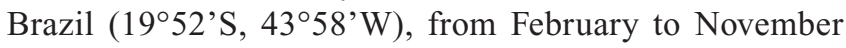
2004. In the region there are two well-defined seasons: the cold dry season receiving less than $50 \mathrm{~mm}$ mean monthly rainfall (April through September), with temperatures ranging from 19 to $21^{\circ} \mathrm{C}$; and the hot rainy season receiving 300 mm mean monthly rainfall (October-March), with mean temperature of $23.9^{\circ} \mathrm{C}$. The area has been protected since 1969 , and has several types of vegetation, including cerrado, and swamps at an altitude of $830 \mathrm{~m}$ a.s.l. (Martins \& Antonini 1994; Loyola \& Martins 2006). Nesting activity of solitary bees and wasps in Brazil is higher in the wet season.

Experimental design. Trap-nests have been widely used to sample solitary bees and wasps (Krombein 1967). Their use improves biological data acquisition on species that build their nests on pre-existing cavities (Koerber \& Medler 1958). Some studies used these species to evaluate the impact of para- site action (Scott et al. 2000) and also to describe nest building process and structure (Camillo et al. 1993; Pereira et al. 1999; Alves dos Santos et al. 2002; Loyola \& Martins 2006).

For this study, we placed trap nests in nine $25-400 \mathrm{~m}^{2}$ square sampling units (henceforth SU, fig. 1 in Loyola \& Martins 2008). Distribution of SU (treatments) in the study area followed a Latin Square design with three treatments $\left(25,100\right.$, and $\left.400 \mathrm{~m}^{2}\right)$ each replicated three times (see Loyola \& Martins 2008). In such sampling design the comparisons between lines and columns are orthogonal among them and also to the treatment, i.e., the comparisons between lines and columns are independent (Underwood 1997; Krebs 1998). We established SU in a 6 ha of secondary mesophytic forest, where trees are medium to large in size, reaching less than $25 \mathrm{~m}$. We defined a minimum distance of $25 \mathrm{~m}$ from any SU, in every direction.

Trap nests were made from compact wood and wooden sticks, measuring $25 \times 25 \times 130 \mathrm{~mm}$ and $11 \mathrm{~cm}$-deep canals with 6,9 , and $12 \mathrm{~mm}$ diameters. We arranged ten sticks of wood from each canal diameter to form a trap nest block, totaling 30 trap nests per nest block. We placed each block on a compound structure made of a $1.5 \mathrm{~m}$ pole, to which a platform was fixed at $1.4 \mathrm{~m}$ above the ground. We then placed five of these blocks in each of the SU: one in the center and the others at each square corner. Hence, we placed 150 trap nests in each SU, making a total of available 1350 nesting sites in the study area.

We inspected trap nests bi-weekly; collected those occupied by bees or wasps, took them to the laboratory, and replaced them by empty ones to keep the number of empty traps constant. In the laboratory, we placed nests individually in small tulle meshes, keeping adults until hatching. Adults were pinned and identified to species or genus (morphospecies).

Statistical analysis. We applied Analysis of Variance (ANOVA) to evaluate the area effect on mean species richness and the mean number and density (i.e., number of nest per unit area) of occupied nests by solitary bees and wasps. We excluded all species that did not occupy a minimum of ten nests during the study period. We grouped the species of the Megaliche genus for the analysis due to their observed common characteristics, such as nest building material, inside nest architecture and providing used material. Further, there is an inherent difficulty of species identification in this genus.

We tested ANOVA residuals for normality (KolmogorovSmirnov test) and for homogeneity of variance (Levene test). We used SYSTAT 10.2 (SYSTAT Software Inc. 2002) for statistical analysis, and established the $\alpha=0.05$ significance level for all probability analyses.

\section{RESULTS}

Four wasp and seven bee species occupied a total of 137 trap nests (see Loyola \& Martins 2006, for details). Wasps occupied the majority of nests $(\mathrm{n}=103,75 \%)$. The remaining trap nests $(n=34,25 \%)$ were occupied by bees. Wasp species 
were Auplopus militaris (Lynch-Arribalzaga 1873) $(\mathrm{n}=53$ occupied nests), Trypoxylon (Trypargilum) lactitarse Saussure $(\mathrm{n}=25)$, Trypoxylon $\mathrm{sp} .(\mathrm{n}=21)$, Sphecidae sp. $(\mathrm{n}=4)$. Bees were Megachile (Ptilosarus) bertonii Schrottky, $1908(\mathrm{n}=6)$, Megachile (Austromegachile) corona Mitchell, $1930(\mathrm{n}=4)$, Megachile (Pseudocentron) sp. $(\mathrm{n}=3)$, Anthodioctes megachiloides Holmberg, $1903(\mathrm{n}=10)$, Centris (Hemisiella) tarsata Smith, $1874(\mathrm{n}=8)$, Xylocopa $\mathrm{sp} .(\mathrm{n}=2)$ and Tetrapedia $\mathrm{sp} .(\mathrm{n}=1)$. Sampling effort was suitable for the study area (see Loyola \& Martins 2008). During the study period, none of the trap nests were occupied by two or more species, and nesting frequency over the year showed consistent patterns associated to each species (Loyola \& Martins 2006).

We found an increase in wasp, but not in bee species richness following the increase of SU size (Table I). Hymenoptera richness (i.e. bees plus wasps) was also greater in larger SU. Both the number and density of nests occupied by bees and wasp also increased with SU size (Table II). Trypoxylon lactitarse responded significantly to area

Table I. The effect of area size on species richness of cavity-nesting bees, wasps and both groups pooled together (i.e. Hymenoptera) during the study period. Degrees of freedom $=\mathrm{df}$, sum of squares $=\mathrm{SS}$, mean square, i.e. variance $=$ MS. F-ratio is the ratio between the variance explained by the effect (area, in this case) and the unexplained variance (residual), thus $\mathrm{F}=$ $\mathrm{MS}_{\text {area }} / \mathrm{MS}_{\text {residual }} . P$ is the probability of obtaining the observed result if the null hypothesis is considered true.

\begin{tabular}{lrrrrc}
\hline \multicolumn{1}{c}{ Source of variation } & df & SS & MS & F-ratio & $P$ \\
\hline Wasp species richness & 2 & 1.626 & 0.813 & 4.528 & 0.021 \\
$\quad$ Area & 24 & 4.310 & 0.180 & & \\
$\quad$ Residual & & & & & \\
Bee species richness & 2 & 6.000 & 3.000 & 1.200 & 0.319 \\
$\quad$ Area & 24 & 60.000 & 2.500 & & \\
$\quad$ Residual & & & & & \\
Hymenoptera species richness & & & & & \\
$\quad$ Area & 2 & 24.666 & 12.333 & 11.385 & $<0.001$ \\
$\quad$ Residual & 24 & 26.000 & 1.083 & & \\
\hline
\end{tabular}

Table II. The effect of area size on the number and density of nests occupied by bees and wasps analyzed together during the study period. Degrees of freedom $=\mathrm{df}$; sum of squares $=\mathrm{SS}$; mean square, i.e. variance = MS. F-ratio is the ratio between the variance explained by the effect (area, in this case) and the unexplained variance (residual), thus $\mathrm{F}=$ $\mathrm{MS}_{\text {area }} / \mathrm{MS}_{\text {residual. }} . P$ is the probability of obtaining observed result if the null hypothesis is considered true.

\begin{tabular}{lrrrrr}
\hline Source of variation & df & SS & MS & F-ratio & $P$ \\
\hline Number of nests & & & & & \\
$\quad$ Area & 2 & 972.667 & 486.333 & 7.984 & 0.002 \\
$\quad$ Residual & 24 & 1462.000 & 60.917 & & \\
Density of nests & & & & & \\
$\quad$ Area & 2 & 1.270 & 0.635 & 34.770 & $<0.001$ \\
$\quad$ Residual & 24 & 0.438 & 0.018 & & \\
\hline
\end{tabular}

size, larger SU having more occupied nests (Table III). The same pattern was exhibited by $A$. militaris, the Megachile species, and A. megachiloides. Only Trypoxylon sp. did not respond to $\mathrm{SU}$ variation in size.

Table III. The effect of area size on the number of nests occupied by the four most abundant Aculeate species during the study period. Degrees of freedom $=\mathrm{df}$, sum of squares $=\mathrm{SS}$, mean square, i.e. variance $=$ MS. $F$-ratio is the ratio between the variance explained by the effect (area, in this case) and the unexplained variance (residual), thus $\mathrm{F}=\mathrm{MS}_{\text {area }} / \mathrm{MS}_{\text {residual }} . P$ is the probability of obtaining the observed result if the null hypothesis is considered true.

\begin{tabular}{lrrrrr}
\hline \multicolumn{1}{c}{ Source of variation } & df & SS & MS & F-ratio & $P$ \\
\hline Trypoxylon (Trypargilum) lactitarse & & & & & \\
$\quad$ Area & 2 & 4.427 & 2.213 & 5.090 & 0.014 \\
$\quad$ Residual & 24 & 10.436 & 0.435 & & \\
Trypoxylon (Trypargilum) sp. & & & & & \\
Area & 2 & 2.186 & 1.093 & 2.751 & 0.084 \\
Residual & 24 & 9.540 & 0.397 & & \\
Auplopus militaris & & & & & \\
Area & 2 & 170.667 & 85.333 & 6.282 & 0.006 \\
Residual & 24 & 326.000 & 13.583 & & \\
Megachile spp. & & & & & \\
Area & 2 & 5.210 & 2.605 & 13.404 & $<0.001$ \\
Residual & 24 & 4.665 & 0.194 & & \\
Anthodioctes megachiloides & & & & & \\
Area & 2 & 18.667 & 9.333 & 4.870 & 0.017 \\
Residual & 24 & 46.000 & 1.917 & & \\
\hline & & & & &
\end{tabular}

\section{DISCUSSION}

We showed that cavity-nesting bees and wasps respond differently to the area effect. A lack of a clear pattern could arise from different sources. First, the species-area relationship on impacted urban habitats can be altered and larger fragments do not necessarily present a higher species number, as observed for social bees (Antonini et al. 2000). On the other hand, the higher wasp species richness found in the larger SU confirmed that larger areas present higher wasp species richness. Similar results were found in a study comparing forested areas to forest remnants varying from 1 to 10 ha (Morato \& Campos 2000). Recently, we have also shown that communities of cavity-nesting bees and wasps respond strongly to vegetation structure at a local scale and that the heterogeneity of particular habitat structure components within a given area effectively predicts cavity-nesting Hymenoptera diversity (Loyola \& Martins 2008, 2009).

Second, Lomolino (2000) points out that in islands with reduced area (up to $40 \mathrm{ha}$ ) it is common to observe the absence of species-area relationship, the so-called "small island effects". These effects occur in small islands where available resource level is not enough to maintain populations of most 
species. In these islands, habitat characteristics, stochastic disturbances, isolation, and interspecific interactions are also likely to determine how many and which species could maintain their populations (Lomolino 2000). Following this reasoning, every area size (latin squares) used in our study, would be too small to allow for a clear species-area relationship, of course. It is curious, however, that wasps in general and that certain wasps and bees species, when analyzed separately, showed a clear response to SU size. Therefore, we may assume that even at a small scale (including experimental areas) the species-area relationship still holds true, although it also depends on the particular species traits, taxonomic group and occurring habitat. Other experimental studies on the small-scale effects of habitat fragmentation have also observed this relationship for ants, butterflies, grasshoppers, gastropods, grass, forbs and vascular plants analyzed as a group (see Zschokke et al. 2000).

Nonetheless, the absence of a clear response by bees is a puzzle. In Central Amazon, bee species richness increased with area size, even in remnants smaller than 40 ha (Morato \& Campos 2000). Ribas et al. (2005) observed that the total number of species in many small remnants (varying from 3.21 ha to $5.56 \mathrm{ha}$ ) was not significantly different from the species number in a large remnant (30.13 ha). Results were different for crickets, which had higher species richness in smaller remnants (Ribas et al. 2005). These results show that area and habitat fragmentation effects could indeed be observed in different scales (Loyola et al. 2006; Loyola \& Martins 2008), and that different taxonomic groups can show diverse responses.

Solitary bees and wasps also showed a positive abundancearea relationship in the studied area. Once again, Morato \& Campos (2000) observed positive abundance-area relationships for solitary wasps and bees in forest fragment and continuous forest areas in Central Amazon. Increase in population density with increasing fragment size, were also reported for Coleoptera (Burke \& Goulet 1998; Didham et al. 1998) and specialist Lepidoptera (Steffan-Dewenter \& Tscharntke 2000). Plant underground biomass is also affected by the size of the experimental areas (Dolt et al. 2005). In another small-scale study Aphidae density was significantly higher in larger areas (Braschler et al. 2003), although the small-scale experimental area size had no effect on ant nest density, when species were analyzed separately, the area effect was significant for the specie Lasius paralienus.

Auplopus militaris is a common species in the fragment and shows restrict ecological tolerance, restricting its nest occupation to the forest interior (Zanette et al. 2004). It is expected that common species in the study area (such as those nesting all over the year) should occupy a greater number of nests in larger SU because, once their populations tend to be large or there is a generation overlapping, individuals can disperse their nests more effectively in space. Dispersion can be explained not only by the species behavior, but also because species is present during longer periods in its habitat. The results found for A. militaris clearly confirm this hypothesis, given that this species occupied a greater number of nests in larger SU and showed a balanced nesting frequency along the study period. Further, the species' response to increasing SU size corroborates the hypothesis that habitat specialists show more evident species-area relationships (Harrison \& Bruna 1999; Holt et al. 1999). The above explanation is equally valid for T. lactitarse, which occupied a greater number of nests in larger SU being also common in the studied area. Note however that T. lactitarse is not a species with a restricted ecological tolerance and the absence of area effect on Trypoxylon (Trypargilum) sp. indicates that particular species respond differently to this factor.

We also found greater nest occupancy by species of Megachile in larger SU. According to the same idea illustrated for $A$. militaris, Megachile species also disperse their nests in a spatial-temporal pattern, due to their relative abundance in the studied area (Loyola \& Martins 2006). Contrastingly, rare species presenting low frequencies of nest occupancy, or presenting population dynamics with peaks in particular periods of the year, concentrate their reproductive efforts in smaller areas and place their nests close to each other (Loyola \& Martins 2006). We confirmed this prediction with the results obtained for $A$. megachiloides, although this species had low frequency of occurrence in the studied area, occupying a greater number of nests in smaller areas. Another Anthodioctes species, $A$. moratoi established a greater number of nests in larger areas (continuous forests) than in forest remnants in Central Amazon (Morato 2001).

Conservation of solitary bees and wasps aims to guarantee the maintenance of at least two fundamental ecological processes in ecosystems: pollination and predation. Further, understanding how these groups respond to area size is essential to support decisions related to species conservation and also of vital ecological processes to the ecosystems functioning. Such understanding must be obviously complemented by information on the frequency and dynamics of area colonization and nest occupancy by species of solitary bees and wasps.

\section{ACKNOWLEDGEMENTS}

RDL is funded by CNPq and CAPES. RPM is supported by CNPq. We thank Elisa Faria, Fernanda Pereira, Lívia Giovanetti, Marcos Figueiredo, Marcelo Moretti and Fábio Borçato for helping during experiment installation/field work. Thanks are also due to Y. Antonini, E. Morato, J. Fontenelle and S. Carvalho for discussions about the experimental design for work execution. We thank three anonymous reviewers for their comments on the manuscript.

\section{REFERENCES}

Alves dos Santos, I.; G. A. R. Melo \& J. G. Rozen. 2002. Biology and immature stages of the bee tribe Tetrapediini (Hymenoptera: Apidae). American Museum Novitates 3377: 1-45.

Antonini, Y.; C. M. Jacobi \& R. P. Martins. 2000. Philopatry in the Neotropical ground-nesting solitary digger bee, Diadasina distincta (Holmberg, 1903) (Hymenoptera: Apidae) at a nesting site in southern Brazil. Revista de Etologia 2: 111-119. 
Braschler, B.; G. Lampel \& B. Baur. 2003. Experimental small-scale grassland fragmentation alters aphid population dynamics. Oikos 100: 581-591.

Becker, C. G.; R. D. Loyola; C. F. B. Haddad \& K. R. Zamudio. 2010. Integrating species life-history traits and patterns of deforestation in amphibian conservation planning. Diversity and Distributions 16: 1019.

Brown Jr., K. S. 1991. Conservation of Neotropical environments: insects as indicators, p. 349-404. In: N. M. Collins \& J. A. Thomas (Eds.). The conservation of insects and their habitats, 15th Symposium of the Royal Entomological Society of London. London, London Academic Press, 432 p.

Burke, D. \& H. Goulet 1998. Landscape and area effects on beetle assemblages in Ontario. Ecography 21: 472-479.

Camillo, E.; C. A. Garófalo; G. Muccillo \& J. C. Serrano. 1993. Biological observations on Trypoxylon (Trypargilum) lactitarse Saussure in Southeastern Brazil (Hymenoptera, Apocrita, Aculeata). Revista Brasileira de Entomologia 37: 459-470.

Cappuccino, N. \& M. A. Martin. 1997. The birch tube-maker Acrobasis betulella in a fragmented habitat: the importance of patch isolation and edges. Oecologia 110: 69-76.

Connor, E. F. \& E. D. McCoy. 1979. The statistics and biology of the speciesarea relationship. The American Naturalist 113: 791-833.

Connor, E. F.; A. C. Courtncy \& J. M. Yoder 2000. Individuals-area relationship: the relationship between animal population density and area. Ecology 81: 734-748.

Colwell, R. K. \& J. A. Coddington. 1994. Estimating terrestrial biodiversity through extrapolation. Philosophical Transactions of the Royal Society Series B: Biological Sciences 345: 101-118.

Davies, K.F.; C. R. Margules \& K. F. Lawrence 2000. Which traits of species predict population declines in experimental forest fragments? Ecology 81: 1450-1461.

Debinski, D. M. \& R. D. Holt. 2000. A survey and overview of habitat fragmentation experiments. Conservation Biology 14: 342-355.

Desmet, P. \& R. Cowling. 2004. Using the species-area relationship to set baseline targets for conservation. Ecology and Society 9: 1-23.

Didham, R. K.; J. Ghazoul,; N. E. Stork \& A. J. Davies. 1996. Insects in fragmented forests: a functional approach. Trends in Ecology \& Evolution 11: 255-260.

Didham, R. K.; P. M. Hammond; J. H. Lawton; P. Eggleton \& N. E. Stork. 1998. Beetle species responses to tropical forest fragmentation. Ecological Monographs 668: 295-323.

Dolt, C.; M. Goverde \& B. Baur. 2005. Effects of experimental small-scale habitat fragmentation on above and below-ground plant biomass in calcareous grasslands. Acta Oecologica 27: 49-56.

Drakare, S.; J. J. Lennon \& H. Hillebrand. 2006. The imprint of the geographical, evolutionary and ecological context on species-area relationships. Ecology Letters 9: 215-227.

Fattorini, S. 2007. To fit or not to fit? A poorly fitting procedure produces inconsistent results when the species-area relationship is used to locate hotspots. Biodiversity and Conservation 16: 2531-2538.

Gonzalez, A. \& E. J. Chaneton. 2002. Heterotroph species extinction, abundance and biomass dynamics in an experimentally fragmented microecosystem. Journal of Animal Ecology 71: 594-602.

Harrison, S. \& E. Bruna. 1999. Habitat fragmentation and large-scale conservation: what do we know for sure? Ecography 22: 225-232.

Holt, R. D.; J. H. Lawton; G. A. Polis \& N. D. Martinez. 1999. Trophic rank and the species-area relationship. Ecology 80: 1495-1504.

Julião, G. R.; M. E. C.Amaral; G. W. Fernandes \& E. G. Oliveira. 2004. Edge effect and species-area relationship in the gall-forming insect fauna of natural Forest patches in the Brazilian Pantanal. Biodiversity and Conservation 13: 2055-2066.

Kier, G.; J. Mutke; E. Dinerstein; T. H. Ricketts; W. Kuper; H. Kreft \& W. Barthlott. 2005. Global patterns of plant diversity and floristic knowledge. Journal of Biogeography 32: 1107-1116.

Krebs, C. J. 1998. Ecological Methodology. 2nd edition. Menlo Park, California, Benjamin/Cummings, 624 p.
Krombein, KV. 1967. Trap-nesting wasps and bees: Life histories, nests and associates. Washington, Smithsonian Press, $570 \mathrm{p}$.

Koerber, T. W. \& J. T. Medler. 1958. A trap-nest survey of solitary bees and wasps in Wisconsin, with biological notes. Wisconsin Academy of Science and Arts Letter 47: 63-63.

Lawton, J. H. 1999. Are there general laws in ecology? Oikos 84: 177-192.

Lomolino, M. V. 2000. Ecology's most general, yet protean pattern: the species-area relationship. Journal of Biogeography 27: 17-26.

Loyola, R. D. \& R. P. Martins. 2006. Trap-nest occupation by solitary wasps and bees (Hymenoptera: Aculeata) in a forest urban remanent. Neotropical Entomology 35: 41-48.

Loyola, R. D. \& R. P. Martins. 2008. Habitat structure components are effective predictors of trap-nesting Hymenoptera diversity. Basic and Applied Ecology 9: 735-742.

Loyola, R. D. \& R. P. Martins. 2009. On a habitat structure-based approach to evaluating species occurrence: cavity-nesting Hymenoptera in a secondary tropical forest remnant. Journal of Insect Conservation 13: 125-129.

Loyola, R. D.; S. L. Brito \& R. L. Ferreira. 2006. Ecosystem disturbances and diversity increase: implications for invertebrate conservation. Biodiversity and Conservation 15: $25-42$.

Martins, R. P. \& Y. Antonini. 1994. The biology of Diadasina distincta (Holmberg, 1903) (Hymenoptera: Anthophoridae). Proceedings of the Entomological Society of Washington 96: 553-560.

MacArthur, R. H. \& E. O. Wilson. 1967. The Theory of Island Biogeography. Princeton, Princeton University Press, 203 p.

Morato, E. F. 2001. Biologia e Ecologia de Anthodioctes moratoi Urban (Hymenoptera, Anthidiini) em matas contínuas e fragmentos na Amazônia Central, Brasil. Revista Brasileira de Zoologia 18: 729-736.

Morato, E. F. \& L. A. O. Campos. 2000. Efeitos da fragmentação florestal sobre vespas e abelhas solitárias em uma área da Amazônia Central. Revista Brasileira de Zoologia 17: 429-444.

Peacock, M. M. \& T. Smith. 1997. The effect of habitat fragmentation on dispersal patterns, mating behavior, and genetic variation in a pika (Ochotona princeps) metapopulation. Oecologia 112: 524-533.

Pereira, M.; C. A.Garófalo; E. Camillo \& J. C. Serrano. 1999. Nesting biology of Centris (Hemisiella) vittata Lepeletier in Southeastern Brazil (Hymenoptera, Apidae, Centridini). Apidologie 30: 327-338.

Rathcke, B. J. \& E. S. Jules. 1993. Habitat fragmentation and plant-pollinator interactions. Current Science 65: 273-277.

Ribas, C. R.; T. G. Sobrinho; J. H. Schoereder; C. F. Sperber; C. LopesAndrade \& S. M. Soares. 2005. How large is large enough for insects? Forest fragmentation effects at three spatial scales. Acta Oecologica 27: $31-41$.

Robinson, G. R.; R. D.Holt; M. S.Gaines; S. P. Hamburg; M. L. Johnson; H. S. Fitch \& E. A. Martinko. 1992. Diverse and contrasting effects of habitat fragmentation. Science 257: 524-526.

Rosenzweig, M. L. 1995. Species diversity in space and time. Cambridge, Cambridge University Press, 436 p.

Schmiegelow, F. K. A.; C. S. Macthaus \& S. J. Hannon. 1997. Are boreal birds resilient to forest fragmentation? An experimental study of shortterm community responses. Ecology 78: 1914-1932.

Schoener, T. W. 1976. The species-area relation within archipelagos: models and evidence from island land birds. Proceedings of the International Ornithological Congress 16: 628-642.

Scott, V. L.; S. T. Kelley \& K. Strickler. 2000. Reproductive biology of two Coelioxys cleptoparasite in relation to their Megachile hosts (Hymenoptera: Megachilidae). Annals of the Entomological Society of America 93: 941-948.

Steffan-Dewenter, I. 2002. Landscape context affects cavity-nesting bees, wasps and their natural enemies. Ecological Entomology 27: 631637.

Steffan-Dewenter, I. \& T. Tscharntke. 2000. Butterfly community structure in fragmented habitats. Ecology Letters 3: 449-456.

Steffan-Dewenter, I. \& T. Tscharntke. 2002. Insect communities and biotic interactions on fragmented calcareous grassland: a mini review. Biological Conservation 104: 275-284.

Sutcliffe, O. L.; C. D. Thomas \& D. Peggie. 1997. Area-dependent migration 
by ringlet butterflies generates a mixture of patchy population and metapopulation attributes. Oecologia 109: 229-234.

SYSTAT Software Inc. 2002. SYSTAT Version 10.2.

Ulrich, W. 2005. Predicting species numbers using species-area and endemic-area relations. Biodiversity and Conservation 14: 33-51.

Tittensor, D. P.; F. Micheli; M. Nystrom \& B. Worm. 2007. Human impacts on the species-area relationship in reef fish assemblages. Ecology Letters 10: 760-772.

Underwood, A. J. 1997. Experiments in ecology: their logical using and interpretation using analysis of variance. Cambridge, University Press, $522 \mathrm{p}$.
Williamson, M. 1988. Relationship of species number to area, distance and other variables p. 91-115. In: A. A. Myers and P. S. Giller (eds.) Analytical biogeography: an integrated approach to the study of animal and plant distributions. London, Chapman \& Hall, $584 \mathrm{p}$.

Zanette, L. R. S.; R. P. Martins; L. A. Soares \& H. R. Pimenta. 2004. Nesting Biology and Sex Ratios of Auplopus militaris (Lynch-Arribalzaga 1873) (Hymenoptera Pomplidae). Tropical Zoology 17: 145-154.

Zschokke, S.; C. Dolt; H. P.Rusterholz; P. Oggier; B. Braschler; G. H. Thommen; E. Lüdin; A. Erhardt \& B. Baur. 2000. Short-term responses of plants and invertebrates to experimental small-scale grassland fragmentation. Oecologia 125: 559-572. 